\title{
The new roles of Legon Botanical Garden as visitor destination in Ghana
}

Eric Cudjoe ${ }^{1}$, Shine Francis Gbedemah" ${ }^{2 *}$

Department of Development and Environmental Studies, Wisconsin International University College, Ghana ${ }^{1,2}$

ekudjo@yahoo.com ${ }^{1}$, fgbedemah@hotmail.com ${ }^{2 *}$

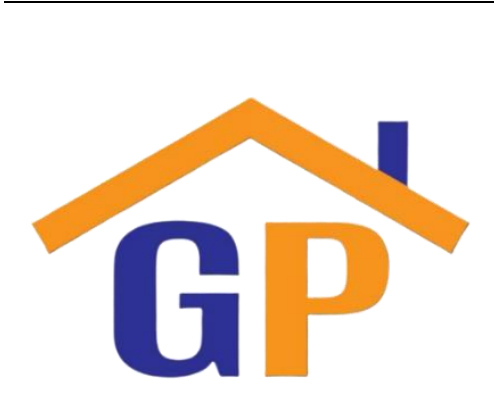

Article History

Received on 22 January 2020

$1^{\text {st }}$ Revision on 27 January 2020

$2^{\text {nd }}$ Revision on 10 February 2020

$3^{\text {rd }}$ Revision on 18 February 2020

Accepted on 19 June 2020

\begin{abstract}
Purpose: This study aims to examine the travel motivations and determine the most attractive facilities of visitors to the University of Ghana's Legon botanical garden in Accra, Ghana.

Research Methodology: The study relied on convenience sampling method to administer structured questionnaires to 127 visitors to the Legon botanical garden.
\end{abstract}

Results: Findings show that the main reason for visiting the garden is to admire the beauty of the garden which is the main reason for establishing botanical gardens. The most attractive facility in the garden, however, turns out to be the canopy walkway and the lawn. Conspicuously missing is the fact that they did not avail themselves to enquire or demand to know tree species and their names in the garden.

Limitations: The study is limited to only adults who visited the garden at the time of the study even though they are on the minority compared to children. Also, the study is limited only to the Legon botanical garden even though it is not the only garden in Ghana.

Contribution: This study contributes to the knowledge in the social sciences by pointing out the most important reasons why people are visiting botanical gardens. This is because the number of visitors seems to be increasing in Ghana. However, the findings show that the visitors do not visit the garden for education, research or conservation purposes but for leisure activities which is not the main reason for establishing these gardens.

Keywords: Botanical garden, Visitors, Motivation, Facilities, Ghana

How to cite: Cudjoe, E., \& Gbedemah, S. F. (2020). The new roles of Legon Botanical Garden as visitor destination in Ghana. Journal of Sustainable Tourism and Entrepreneurship, 1(1), 23-35.

\section{Introduction}

A botanical garden can be said to be a place that is open to the public and in which labelled plants can be found (Powledge, 2011). This simple definition of botanical garden has been enlarged to include a collection of living plants grown outdoors, either naturally or in greenhouses and conservatories. Others also defined botanical garden as a collection of living plants that are scientifically managed for the purpose of education, research, conservation and community use (Ankoma, 2014; 1). Botanical gardens attract a large number of domestic and foreign tourists (Ballantyne et al, 2008) but local visitors use botanical gardens to pursue education, learning, and leisure activities (Crilley et al., 2010). Although statistics available on global botanical gardens visitations are fragmented, they are generally considered as an important form of leisure activity destination.

Ghana has five Botanical gardens. They are the Kwame Nkrumah University of Science and Technology (KNUST) Botanic Garden in Kumasi, the University of Ghana Botanical gardens in 
Legon-Accra, the University of Cape Coast Botanic Garden in Cape Coast, the Bunso Arboretum in Bunso and the Aburi Botanic Gardens in Aburi. The Aburi Botanic gardens, which is about 32 kilometers from the Legon Botanical Garden (LBG), is the oldest and the biggest in Ghana. It was established in 1890 by the British colonial government of the Gold Coast. It occupies an area of about 64.8 hectares of land. Out of the 64.8 hectares, 12.2 hectares have been developed into a formal garden where people can visit and relax. The remaining 52.6 hectares formed the botanical reserve of the Aburi Botanic garden.

Legon Botanical Garden (LBG) is owned by the University of Ghana and managed by both the Department of Plant Biology and Environmental Studies of the University and Mulch Company Limited, an environmentally friendly management firm. It was originally established in the year 1948. The garden is made up of natural vegetation with a total area of 50 hectares of which 38 hectares is landscaped. It has facilities like a dam, arboretum, herbarium, seed bank, and tissue culture center. Legon Botanical Gardens is located in the La-Nkwatanang District of the Greater Accra Region (Longitude: -0.2065 and Latitude: 5.5447 ). This botanical garden has a collection of flora and fauna, cocoa, timber trees, fruit, and medicinal plants. According to Botanic Gardens Conservation International, the Legon Botanical garden was designed to cater for both the educational and leisure needs of students of the University of Ghana, Legon.

However, with time, the leisure demands and preferences of people or visitors to the LGB has caused a major shift in the gardens' mandate. This deviation has led to management making the Legon botanical gardens assume a new role of making it a place where people interact with nature. To further this end, visitors are allowed to undertaken leisure activities with their families and friends to strengthen their unity through interactive play. In furtherance of these goals, the management of the garden installed facilities for all persons irrespective of age, which provides lessons, fun, and a wonderful experience. These activities include children's playground with first-class play equipment, high rope courses made up of series of platforms connected by cables wood and rope, creating different challenges at each platform for adults; junior rope course and obstacle challenge for children; canoe riding; a 110-meter long high canopy walkway. Additionally, there are grounds for picnic activities, biking and bird watching.

This deviation from the Botanical Gardens' core activities such as collection and maintenance of plant species especially those threatened, promoting plant conservation, keeping a herbarium and arboretum for research and ornamental purposes as well as providing environmental education and extension services has made the garden a place where revelers want to be. Though the conversion of the garden to cater for the needs of such clientele could have its consequences, yet there is the need and demand for it. Because, most people in this part of the world (Africa) Ghana in particular, do not see the need to visit botanical gardens for its proper utilization like maintaining plant species, plant conservation, ensuring viable herbarium and arboretum for educational research and ornamental purposes, extension services, just to mention few, additional recreational activities have been added to serve as an added impetus which pulls citizens to the garden from all over the country. "The attachment of visitors to destinations is strongly related to the attractiveness of the destination, the satisfaction with the destination, past experience and age of visitors" (Owusu, 2001; 191). It may also be argued that the best memories of a destination in the minds of visitors are largely influenced by the satisfaction derived from attraction or activities at the destination like the Legon botanical gardens. The satisfaction derived from attraction, therefore, play an important role in creating pre-trip expectations, actual trip experiences and post-trip memories (Frempong, et al., 2015). This study, therefore, set out to understand patrons' satisfaction with attractions at the Legon botanical garden.

\section{Literature review and hypotheses development}

2.1 Concepts of botanical gardens

The characteristics of botanical gardens, according to the Botanical Gardens Conservation Strategy (IUCN-BGCS \& WWF, 1989) should include the following:

- An underlying scientific basis for the collections;

- Communication of findings to other gardens, institutions, organizations and the public; 
- Exchange of seeds or other materials with other botanical gardens, arboretum or research stations;

- Long term commitment to, and responsibility for, the maintenance of plant collections;

- Maintenance of research programs in plant taxonomy in associated herbaria;

- Monitoring of the plants in the collection and opening of the garden to the public;

- Promoting conservation through extension and environmental education activities;

- Proper documentation of the collections, including those of wild origin;

- Undertaking scientific or technical research on plants in the collections.

The Legon botanical garden can be said to fit perfectly into these characteristics making it one of the attractive destinations to people in the country.

Smith (2019) points out that a garden containing scientifically ordered and maintained collections of plants, usually documented and labelled, and open to the public for the purposes of recreation, education and research (Ankoma, 2014; 5) is a Botanical garden. In the context of the BGCI, the use of the term 'botanical gardens' should be interpreted to include arboretum and other specialized forms of plant collection. Despite difficulties in deciding which institutions merits to be included in the list of botanical gardens worldwide, it is widely believed that majority of botanical gardens, arboretum and similar institutions worldwide holds significant ex situ collections of living plants (Wyse-Jackson, 1999). An Arboretum is a place where trees shrubs and herbaceous plants are cultivated for scientific and educational purposes (Wassenberg, 2012).

Today's botanical gardens are strictly protected natural green areas with a managing organization who creates landscaped gardens and holds documented collections of plants with some animals for purposes such as scientific research, education, public display, conservation, sustainable use, tourism and recreational activities (Ankoma, 2014; 5). Presently, botanical gardens have evolved to have expanded programming such as the conservation of plant biodiversity. They also serve as priceless repositories of plant germplasm for the long-term preservation of species (Abdulhameed et al. 2017). To satisfy the changing nature of botanical gardens, the Legon botanical garden is now got the vision and mission of being a tropical botanical garden of international repute in the eco-tourism industry to create an environment where people conference with nature. The garden hosts about 69,630 visitors per annum. The question, what is, the motivation driving people to visit the garden? This is discussed in the next section.

\subsection{Motivation of people to visit destinations}

Motivation according to Uysal \& Hagan (1993) is mostly described as biological or psychological desires and needs. It essentially has forces that produce, direct, and incorporate an individual's conduct and action (Dann, 1981). An important consideration when assessing the perception and emotional involvement of visitors is the motivation of people to visit a destination. Yao $(2013 ; 18)$ posits that motivation is "a meaningful state of mind which adequately disposes an actor or a group of actors to travel." According to this author, motivation is the "driving force" that stimulates people to participate in visits and travel activities. Factors that affect the motivation of visitors include both the personal characteristics that visitors bring with them to the visit, such as personal goals and capabilities, beliefs and situational characteristics setting of the destination, such as opportunities for learning, and aspects that arouse interest (Packer \& Ballantyne, 2002). These authors also established that the impact on the selective direction of behaviour (the choice of one action over others), energization of behaviour (the amount of energy or effort expended) and persistence of behaviour (its maintenance over time). These behavioural patterns, in turn, lead to various desired outcomes such as attainment of personal growth or life satisfaction (Packer \& Ballantyne, 2002).

Iso-Ahola (1982), proposed a "seeking intrinsic rewards" model to explain motivation, under which motivations were assessed from two forces: seeking and escaping. The seeking force was explained as "the desire to obtain psychological rewards from travel," and the escaping force is referred to as "the desire to leave everyday environment" (Iso-Ahola, 1982). In a later study, Gnoth (1997) designed a motivation-expectation model to investigate tourists' attitudes toward the travel experience. His model described and assessed the formation process of motivation by examining tourists' inner needs 
and values. Another commonly accepted theory in understanding tourists' motivation is the "travel career ladder" (TCL), which was adopted from Maslow's hierarchy of needs theory. Figure 1 shows the Travel Carrier Ladder.

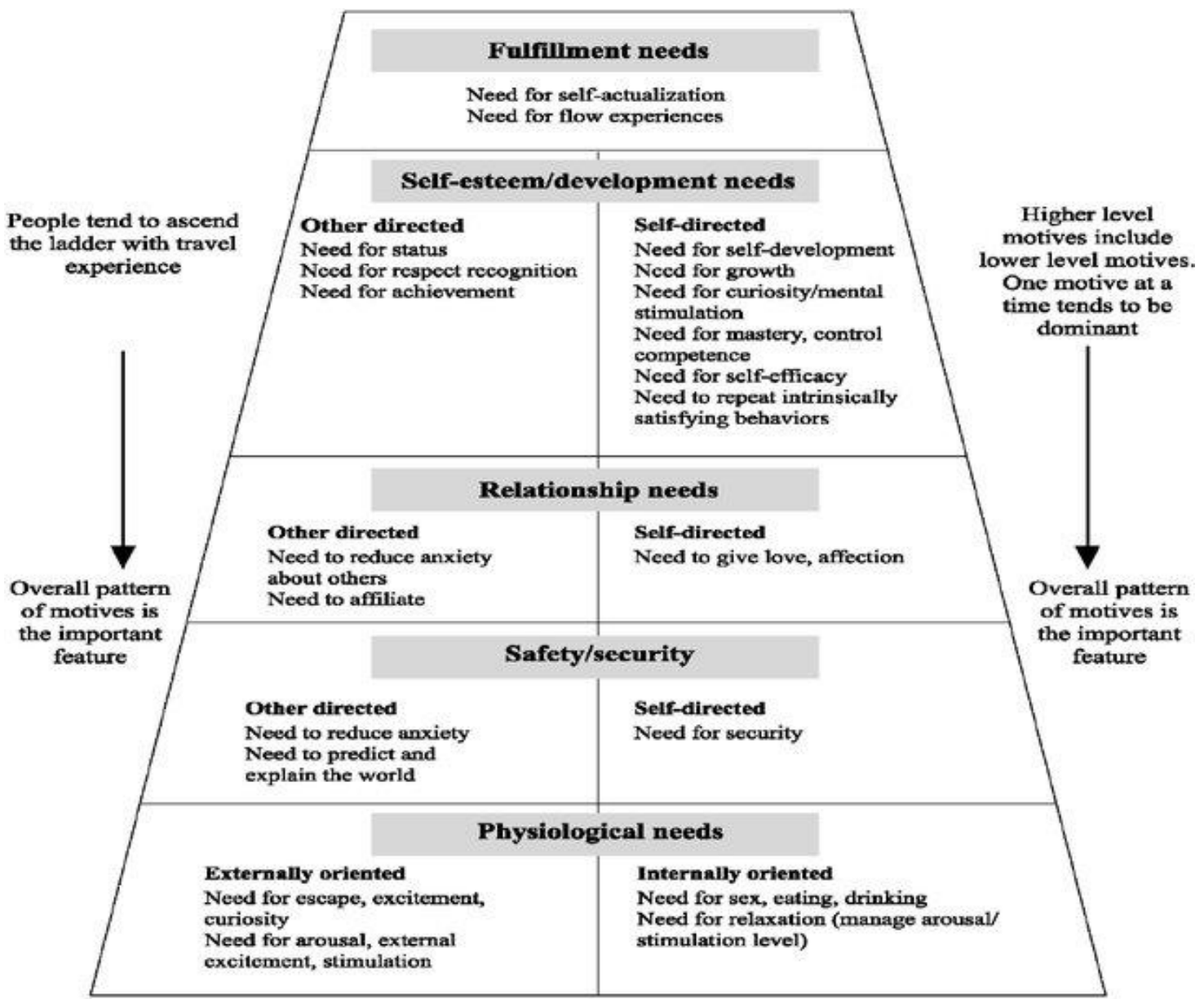

Source: Pearce (1991)

\section{Figure 1: Travel Career Ladder (TCL)}

Tourists' motivations were classified into five levels starting with physiological needs as the lowest, followed by safety/security, relationship needs, self-esteem/development, with fulfilment needs as the highest level. The TCL approach indicates that visitor or tourist's motivation to visit a destination could vary and change based on different needs at different times (Wong \& Musa, 2014; 7). In the contexts of visiting a botanical garden like the one at Legon beyond the general motivations, the specific influence of relaxation or recreation and enjoyment of nature and its aesthetic value as well as other dimensions such as knowledge-seeking and adventure experienceseeking can be the driving force. This is because, the botanical garden have been around for many years and since the main aim of the garden is to establish profound connection between humans and living plants, they also end up establishing curiosity, mental stimulation and above all, need for selfactualization.

The following are some of the reasons why people tend to visit botanical gardens:

- According to Ballantyne et al. (2008), the beauty and serenity of gardens plays a major role in attracting visitors and the legon Botanical garden is not exempted from this;

- You can see and learn about a wide variety of plants you might not see where you are;

- It is an appropriate venue for family relaxation through play and related activities;

- It is a place to overcome stresses of our daily life activities (Wassenberg, 2012); and 
- The desire to immerse one's self in living plants and enjoy peace, because of human and plant connection which has been around for many years.

\subsection{Visitor satisfaction}

Early concepts of satisfaction research have typically defined satisfaction as "a post-choice evaluative judgement concerning a specific purchase decision" (Homburg \& Giering, 2001; 44). Customer satisfaction is often used to refer to the satisfaction of an individual's consumption experience or service encounter. It has also been described as a summary evaluation of a customer's overall experience with an organization or its products (Cronin \& Taylor, 1992). Another author argued that visitor satisfaction 'is an intervening variable that mediates the relationship between service quality judgements and behavioural intentions' (Crilley et al., 2010; 479). These authors furthermore suggested that service quality is one of the primary drivers of visitor satisfaction. The physical attribute performance also has a degree of influence on visitor satisfaction. This refers to the perceived performance of the functional attributes of a destination, these are service quality, location, and physical attractiveness (Yao, 2013; 12). The critical role of attribute performance in determining visitor satisfaction has been widely discussed and supported by several studies. Pizam et al., (1978) were proposed that the measurement of tourist satisfaction should be based on identifying and measuring the dimensions of destination performance. These authors also posit that equal attention should be given to each attribute of the destination because the perception formed about any of the attributes could lead to satisfaction or dissatisfaction with the overall visitor experience. Another idea that supports the connection between destination performance and satisfaction is the one by Chen \& Chen (2010) which proposed that there are connections among experience quality, perceived value, satisfaction, and behavioural intention. In their study, the perceived value actually referred to the evaluation of attribute performance. To this end, satisfaction may simply be said to be the emotions and contentment felt towards a destination (Tlili \& Amara, 2016).

Significant progress has been made by tourist destinations to ensure satisfaction of visitors towards the destination but one of the most important objectives in the leisure and recreational industry today is providing total customer satisfaction" (Carev, 2008, p. 17). This author further opined that researchers are still trying to determine the conceptual and empirical distinctions between customer satisfaction and service quality. To date, however, the relationship is not universally agreed upon. In fact, in many instances, customer satisfaction and service quality are used interchangeably (Carev, 2008). To this end, visitor satisfaction experience can be analysed in two interesting parts, the encounter with the core attraction itself on one hand and the services that are consumed from the patronage of the attraction. In a sense this fits into Frempong, et al., (2015) categorization of "landscapes" (the physical attractions themselves) and "sensescapes" (which involves various senses as an important component of the tourist experience).

Visitor satisfaction is considered to be one of the most important outcomes of all marketing activities in market-oriented establishments (Canny, 2013). The obvious need for satisfying the business' customer is to expand the business, to gain a higher market share, ensure repeat visits and referral of the business, all of which lead to improved profitability (Carev, 2008; 17). This is because satisfied customers purchase more each time they visit and purchase more often. The satisfied customer also refers businesses or destinations to their family and friends.

\section{The study area and research methodology}

The study site is the Legon Botanical Gardens (LGB) in the Greater Accra region of Ghana. The site is located within the University of Ghana reserved land area and covers an area of approximately 25 hectares of land (Ankoma, 2014; 16). Legon Botanical Gardens was chosen for this research because it happens to be the most known and available recreational and leisure centre of its kind in the city of Accra. It also has a good number of different developed attractions. These activities are; children's playground with first class play equipment, high rope courses made up of series of platforms connected by cables, wood and rope, creating different challenges at each platform for 
adults; junior rope course and obstacle challenge for children; canoe riding; a 110 meter long high canopy walkway. Additionally, there are grounds for picnic activities, biking and bird watching.

Though these leisure and recreational activities deviate from the core mandate of botanical gardens in Africa such as; collection and maintenance of plant species especially those threatened, promoting plants conservation, keeping a viable herbarium and arboretum for educational research and ornamental purposes as well as providing environmental education and extension services, these activities are needed to keep the place alive. This is because most people in Ghana do not see the need to visit botanical gardens for its proper utilization as it pertains to the developed world. Hence, adding these recreational activities serves as an added impetus that pulls citizens to the botanical garden.

This study used the descriptive study design method (Floy, 2015). This method is about how reality actually is. A convenience sampling method was used to gather data from visitors to the garden. This method was used because it is a type of non-probability sampling method which allows for a sample to be taken out of the total group or population. The data collected is then analysed for it to be considered as a representative of the entire group or population (Nworgu, 1991). In addition to this reason for using the convenience sampling method is the fact that, visitor inflows to the botanical gardens vary depending on the time of the day, day of the week, season and public holidays (Frempong, 2015; 112).

A population can be said to be all objects, or members that are in a group. Thus, the population for this study is the total number of visitors that patronize the LBG. Available data on visitor inflows for the LBG for the year 2018 stands at 62,000 people, children inclusive since they are on the majority. The study was conducted with this 62,000 of visitors in mind. The aim is to use at least one percent of the total adult visitor population of the garden. As a result, a sample frame of 127 visitors was selected to participate in this study. This is justified on the grounds that it is acceptable to use a part of the total population as a sample to make an inference or arrive at a scientific conclusion that could represent the overall population (Diako, 2012; 98).

As already pointed out, a convenience sampling method was used for the study. This means data was gathered from the visiting tourists available who are willing and ready to answer the questions. Intercept location points were selected in consultations with the garden's management, such that, visitors were not inconvenienced unduly. This was on a 'next-available' basis, as affirmed by Crilley et al., (2010). Visitors to the garden in school groups and attending special events were not included in the study. Though the downsides of this method are that, results obtained could be biased and might not be ideal to generalize it to the targeted population, it has the added advantage of gathering needed data in the shortest possible time since it does not need to be conducted on the whole population.

Data for this study was collected using structured questionnaires personally administered to the visitors who could not read and write English. The instrument contained both closed-ended and openended questions. Those visitors who could read and write and willing to fill the questionnaire were allowed to complete it themselves on the study site. This was done on weekends as well as public holidays that fall within March, April and June 2019. The survey gathered data on visitor characteristics, (i.e. age, gender, marital status, occupation, and education), visitor expectations at the site in terms of its attractions and motivation of visitors and their expectations. They were asked to assign a value to visitor expectations at the site in terms of its attractions and motivation of visitors and their expectations already determined answer with the last option allowing them to state what their answer is. At times, a Likert scale (Zhang \& Chan, 2016) was used. The data gathered was analysed to check for missing values and outliers with the aid of Statistical Packages for Social Sciences (SPSS). The data was scrutinised to obtain results in terms of frequency, percentage, and mean so as to meet the outlined of two objectives. A ranking is done to show the most important item that the respondents mentioned as is of interest to them. The data is transformed into numerical or ordinal values to show the highest and the lowest data. The ranking shows the popularity of the items. 


\section{Results and discussions}

\subsection{Demographic background of respondents}

Out of 130 questionnaires that were administered at the Legon botanical garden, 127 were found to be good for analysis. This gives a success rate of $(97.7 \%)$. The data indicates that 59 respondents, representing $46 \%$ are males and females are 68 , constituting $54 \%$ of all respondents. According to Ghana's population census (GSS, 2010), there are more females than males in the population of Accra, and Ghana as a whole. Hence this could be the reason for more female respondents than males in the study. Not only that but also due to the fact that female visitors to the garden were more willing to complete the questionnaires or grant interviews. This study, therefore, agree with $\underline{\text { Singer, Hoeyk \& }}$ Maher (2000) and Moore \& Tarnai (2002) that women are more likely to participate than men in survey studies especially those that use traditional modes of survey administration as done in this study.

In terms of age distribution, 56 of respondents representing $44 \%$ are between $26-35$ years of age. The reason for this age group being the majority could be attributed to the fact that most young couples with or without children fall within this age bracket and in the prime of their working lives. Hence are most likely to seek the garden's environment and ambience to relax and reduce stress or want to be rejuvenated. Again from the data, 47 respondents (37\%) who are between 18-25 years are mostly adult tertiary students or young adults who have completed a first degree and are working or offering national service. And often have the desire to explore places of leisure to mingle, make new friends and have fun. The findings further show that 16 respondents constituting (13\%) fall within the ages of 36-45. This could also be due to the fact that they are within mid-ages and might not be interested in moving around the gardens but rather choose to relax more at a particular place leading to them having time to participate in the study. Table 1 is the age distribution of the respondents of this study.

Table1: Age Distribution of Visitors to LBG.

\begin{tabular}{|l|c|c|c|}
\hline Age Group (Years) & Number & Percentage (\%) & Rank \\
\hline $18-25$ & 47 & 37 & 2 \\
\hline $26-35$ & 56 & 44 & 1 \\
\hline $36-45$ & 16 & 13 & 3 \\
\hline $45-55$ & 8 & 6 & 4 \\
\hline Total & 127 & 100 & \\
\hline
\end{tabular}

Source: Field Work (2019)

When it comes to education, the majority of respondents (58.3\%) had tertiary education as can be seen in Table 2 below. This can equally be attributed to the closeness of the garden to other tertiary institutions. There are many universities within the catchment areas of the botanical garden. The University of Ghana, Wisconsin International University College, Ghana, University of Professional Studies, Accra, Valley View University just mention a few. Also, Madina and its environs as well as settlements, are mostly inhabited by the middle class, and usually, these are people with at least tertiary education. Additionally, people with tertiary education may understand and appreciate the benefits of botanical gardens more than those with lower-level education. Affordability or ability to pay could also be another factor leading to the high respondents being within the tertiary educational level. Table 2 shows the level of education of respondents.

Table 2: Level of Education of Visitors

\begin{tabular}{|l|c|c|c|}
\hline Education & No. of people & Percentage & Rank \\
\hline Non-Formal Education & 8 & $6.3 \%$ & 3 \\
\hline Junior Secondary & 6 & $4.7 \%$ & 4 \\
\hline Senior Secondary & 39 & $30.7 \%$ & 2 \\
\hline Tertiary & 74 & $58.3 \%$ & 1 \\
\hline Total & 127 & $100.0 \%$ & \\
\hline
\end{tabular}


Whereas people with tertiary and senior secondary qualifications are more likely to be gainfully employed for them to be able to afford the fees charged at the gardens, which accounts for their large number in the study, those with junior secondary and non-formal education could only manage (4.7\%) and $(6.3 \%)$ respectively. This can be due to the fact that most people in this bracket are not financially sound enough so finds it difficult to afford entrance fees and individual activity rates.

\subsection{Motivation of visitors \& their expectations}

The "push and pull" factors are frequently applied when explaining what influences people to visit destinations (Baloglu \& Uysal, 1996; Chan \& Baum, 2007; Crompton, 1979). The push motivation relates to people's inherent incentive to visit, which means people's desire to move (Swarbrooke, 1999). On the other hand, the pull motivation is agreed to be destinations' own attributes or attractions there which invites/attracts people to come and visit (Ritchie, et al., 2010). The expectation of a pleasurable and memorable experience also motivates lovers of nature to visit destinations like a botanical garden and enjoy attractions, services and natural environment (Frempong, et al., 2015; 108).

Data from the study shows varied reasons which motivate respondents to visit the LBG. To understand these, there is the need to bring in the Travel Career Ladder (TCL) of the needs of visitors or tourists. The Travel Carrier Ladder classified visitors into five levels starting with physiological needs-relaxation, followed by safety-stimulation, then relationship nneds, self-esteem and development needs, and fulfilment needs as the highest level (Pearce, 1991). The TCL approach indicates that visitors or tourist's motivation to visit a destination could vary and change based on their different needs. To this end, close to half of the total respondents (48\%) said they were motivated to visit the garden so they can admire nature's beauty. This response could have been driven by the safety/security and physiological needs on the TCL ladder which says those people want to satisfy the internally oriented need of escape, excitement, and curiosity. The (14.2\%) that were motivated by a desire to take a look at the garden to know what is on offer at the destination in terms of attractions, can equally be attributed to satisfying their curiosity and external excitement under physiological needs. This expectation of the respondents could have been largely influenced by word of mouth narration received from friends and family who had visited previously and found attractions in the garden enjoyable and satisfactory. Additionally, knowing what is available at the garden in terms of activities or attractions enables visitors to know what exactly they are going to do in the garden, hence, this high majority of respondents saying they want to have fun.

About $12.6 \%$ of the respondents were in the LBG for an adventure which on the TCL can be equated to the level of self-esteem/development. Under this is status, need for repeat recognition and the need for achievement. Some of the respondents point out that they were in the LBG to climb the canopy walk-way (11\%), which within the TCL is also the satisfaction of curiosity and achievement under self-esteem/development. Other respondents were also in the garden to relax with their children at the playground (7.9\%), which can be said to be due to the satisfaction of affiliation with family and reducing anxiety under the relationship needs level of the ladder. Other reasons assigned for visiting the garden are to climb the obstacle courses $(3.1 \%)$, which on the TCL is the satisfaction of mastery, control, and competence of the self-esteem/development level. The rest of the responses can be seen in Table 3.

\section{Table 3: Motivation to Visit Legon Botanical Gardens}

\begin{tabular}{|l|c|c|c|}
\hline Motivations for Visiting LBG & Number of Responses & Percentage & Rank \\
\hline For participation in the obstacle courses & 4 & $3.1 \%$ & 6 \\
\hline Climb the canopy walkway & 14 & $11 \%$ & 4 \\
\hline To take a look around and see what is here & 18 & $14.2 \%$ & 2 \\
\hline For adventure and to have fun & 16 & $12.6 \%$ & 3 \\
\hline To admire the beauty of nature & 61 & $48 \%$ & 1 \\
\hline To relax with my children & 10 & $7.9 \%$ & 5 \\
\hline
\end{tabular}




\begin{tabular}{|l|c|c|c|}
\hline To have canoe ride on the lake & 2 & $1.6 \%$ & 7 \\
\hline No comment & 2 & $1.6 \%$ & 7 \\
\hline Total & 127 & $100 \%$ & \\
\hline
\end{tabular}

Source: Field Work (2019)

These responses were made by the respondents mainly because, the LBG has activities for visitors' enjoyment like children's playground with good and child-friendly play equipment; high rope courses made up of series of platforms connected by cables wood and rope, creating different challenges at each platform for adults; Junior rope course and obstacle challenge for children; canoe riding and a 110-meter long high canopy walkway. The garden's canopy walkway, which suspends from the forest's layer, allows scenic views of the garden's trees. The walkway provides better viewing of the forest and the nearby environs by visitors.

Additionally, there are grounds for picnic and related activities, biking and bird watching. All these attractions can satisfy the recreational demands of visitors to the garden. But when it comes to wildlife and seeing them in the open, the LBG is not a place for these. Because, most game and big mammals are not available, however, small mammals like glasscutters, king-rats, squirrels, bats, birds, and monitor-lizards can easily be sighted. So, depending on the type of animals individual visitors wanted to see, they will either be happy or not satisfied with this aspect of the garden.

From Table 3 above, one can deduce that some respondents are very much in love with natural environment settings comprising of trees, vegetation, flora, and water bodies which are the core mandates of establishing botanical gardens. So they had the expectation of seeing and experiencing pure nature in the garden. Some also are of the opinion that the atmosphere and attractions at the gardens will help them have a well-deserved good rest and relaxation.

\subsection{Most enjoyed attraction in the garden}

Satisfied visitors mostly spend and buy more at a destination (Munier \& Camelis; 2013). The more visitors spend, the more that would be sold, when more are sold, profits increase (Carev, 2008). In addition, satisfied customers are less likely to seek the lowest prices and the cost of selling to them is much less than the cost of capturing new customers from the competition. Therefore, literature advises that attention should be given to each destination attribute because the perception formed about any of the attributes could lead to satisfaction or dissatisfaction with the overall visitor experience (Yao, 2013). This in mind, this study deemed it appropriate to ask respondents' views on aspects and attractions in the garden they enjoyed most. Out of the 127 people interviewed, majority, of about 82 visitors representing (64.6\%) chose a combination of the canopy walk and the lawn as their preferred and most enjoyed attractions. The underlying factor for this majority preference is that the canopy walk-way is a flagship attraction, not only in Ghana but the world at large for both local and foreign tourists (Seibel, 2013). The experience is highly sought for, yet to have access to it in Ghana, one has to travel to Kakum in the Central Region of Ghana which is about 178 kilometers away from Accra, before Legon had its own constructed. Though there are others in Eastern Region, safety-wise, Kakum is the benchmark and Legon botanical garden's canopy walkway is next to Kakum when it comes to safety. Moreover, young people and children are able to enjoy this canopy walkway due to its short course and low height compared to the Kakum walkway, 350 metres long at 40 metres height, leading to the high number of responses on most enjoyed attractions in the garden.

Table 4: Most enjoyed attraction in the LBG

\begin{tabular}{|l|c|c|c|}
\hline Groups & No. of people & $\begin{array}{l}\text { Percentages } \\
(\%)\end{array}$ & Rank \\
\hline Playground \& aesthetic view & 19 & 15.00 & 3 \\
\hline Canopy walk and the lawn & 82 & 64.6 & 1 \\
\hline Bird watching \& canoe ride & 5 & 3.93 & 4 \\
\hline Obstacle course \& zip-line & 21 & 16.53 & 2 \\
\hline Total & 127 & 100 & \\
\hline
\end{tabular}

Source: Field Work (2019) 
Also, $15 \%$ of the respondents chose the playground and aesthetic view of the garden, as their most enjoyed attractions. The Legon botanical garden has one of the best aesthetic view, collection of flowers and ornamental plants in the country. The beauty is awe-inspiring in quality, and lovers of natural flowers cherish it so much. The beauty of the garden is indescribable when one visits during the start of the rainy season. This is when all brown lawns turn green with different colours. One's breath is easily taken away during this time. The obstacle course and zip-line, on the other hand, comes with the thrill of hanging high up on a cable attached to two tall tree points, then swinging at a fast speed from one end that slopes down to the other end. Lovers of adventure like it a lot thus influencing the decision of respondents who chose this set of attractions as their best.

Bird watching and a canoe ride on the lake is the attraction that visitors to the LGB claimed they enjoyed least. The thrill of being ridden on the canoe through the islands and peninsulas that are the sanctuary of the birds does not seem to be thrilling to our respondents enough. Even though this facility of the LBG is attractive enough, the majority of the respondents do not seem to like it. The season can be attributed to the type of clientele that visits the garden, mostly the youth who do not like being ridden in a small canoe with paddles. Also, bird watching seems to be the favourite of people within their middle and old ages leading to it being the least enjoyed facility. These findings can be said to be a true reflection of what pertains to the garden. For example, the distance for the canoe ride is not all that long. It starts from the banks of the lake to around one of the islands and back in a single cycle. For some respondents who said they were afraid or scared on the water leading to it being the least preferred facility. The findings further revealed that those who chose birdwatching as least interesting to them said they did not find many birds flying around except the flock of cattle egrets that have their nesting and roosting site on trees on the islands on the lake. Birds are generally active in the early mornings and non-active when the sun is up, then become active again just before sun-down. Bird enthusiasts are known as birdwatching-freaks or birdwatchers, they are mostly conservationists, lovers of nature and lovers of animals. It is a very popular hobby as well as fauna protection activity in the Americas, Europe and other parts of the world.

In Ghana currently, birdwatching is not very popular with a majority of the populace due to people not having an interest in it, though it is one of the ways people can exercise their bodies to keep fit and admire nature's beauty. It is done by walking around for some distance to watch birds in flight and those perching on trees with the aid of a pair of binoculars and a bird guide (book defining birds). Some tour operators in Ghana are doing their best to promote it to foreigners because Ghana has over 760 species of beautifully coloured birds. A non- governmental organization, Ghana Wildlife Society (GWS) is leading the drive for creating awareness for birdwatching by forming wildlife clubs in first and second cycle schools and educating club members on how to watch, protect and conserve birds and wildlife in general.

The findings discussed above reveal an interesting and important finding on the new role of botanical gardens. Even though some respondents indicated their love for nature and flora in general, conspicuously missing was the fact that they did not avail themselves to enquiring or demanding to know tree species and their names in the garden. According to Powledge $(2011 ; 743)$, "the purpose of these gardens has greatly expanded to include rescuing plant biodiversity, offering serious programs of research and education to citizens of all ages and instruction for skilled botanists, creating aesthetically pleasing refuges from modern life, and maintaining storage centers both on-site and offsite for the long-term preservation of plant species against the time when they will have vanished from their usual habitats". Going round the LBG, one can observe some timber trees, ornamental plants, and fruit trees in the garden that have been labelled with both local and scientific names. However, there is no record of any of the respondents mentioning anything about trees throughout the research.

This is indicative of people's mentality and attitude towards conservation of trees and knowing their names, their uses, medicinal properties as well as the environmental benefits of having more trees around humanity. In this part of the world, Ghana in particular and Africa in general, citizens and visitors to botanical gardens usually only pay attention to the recreational aspect of such botanical gardens and neglect other vital or key components like trees and plants. This finding is not an isolated 
case because Ballantyne et al. (2008) and Ward et al. (2010) established that visitors who patronize botanical gardens usually are more motivated by non-horticultural or educational purposes. It was reported that "return visitors to botanical gardens were more interested in relaxation than education (Wassenberg et al. (2015; 153) which is the case in our current study.

\section{Conclusion}

In explaining the changing role of botanical gardens, this current paper contributes to the literature that explores the reasons why people are visiting botanical gardens since the number of visitors seems to be increasing in Ghana. For instance, Botanic Gardens Conservation International points out that Aburi botanic gardens currently are hosting around 75,000 visitors while that of Legon botanical gardens attracts about 69,630 visitors per annum. These numbers do not visit the garden for education, research or conservation but for leisure activities. This, therefore, calls for a deliberate and concerted effort towards more sensitization and educating the citizenry and the visiting public who patronizes our botanical gardens, by botanist on the importance and needful nature of trees to the human and animal ecosystems. Because, as the saying goes, "when the last tree dies, the last man equally dies".

The Legon botanical garden staff should deploy their expertise to support practical conservation, management and use (Smith, 2015). LBG need to demonstrate the value of their collections. This is because, botanical gardens in Ghana have become serious income-generating and at the same time, ecosystem, forest, habitat, and biodiversity protective ventures. Hence every possible means through which we can protect the environment must be explored. The uses of botanical gardens are rapidly becoming centers of tourist attraction for those seeking natural settings to relax and 'de-stress', since it is easier for them to access these gardens than to travel long distances to national parks or forest reserves to have interaction with nature. This new role must and should be encouraged yet managed sustainably in order to check over usage or overexploitation. So as to enable future generations to have access to these gardens as we do now. Care must be taken not to unduly distort the natural environment and biodiversity habitats. Additionally, new plant and animal species introductions must be done well to avoid contamination of the existing ecosystem and biodiversity.

\section{Limitation and study forward}

This study is limited to only adults who visited the garden at the time of the study even though they are on the minority compared to children. Also, the study did not cover all the botanical gardens in Ghana. Covering all the botanical gardens in the country would have helped to confidently conclude that, this is the situation in Ghana but this could not be done. In conducting future work on botanical gardens in Ghana, this study is recommending that the study should be conducted with all children and adults to compare their motivations. Also, the study should be conducted in all the botanical gardens in the country.

\section{Acknowledgement}

The authors would like to acknowledge the support of the Director, Legon Botanical Gardens Mr. Kofi Boakye for making this study possible. The help of management and staff of Legon Botanical gardens especially, Mr. Charles Amoako Asare is well appreciated. The authors also acknowledge all visitors who spent their time to make the study successful. This paper would be of great importance in the development of tourist sites in Ghana and Africa as a whole.

\section{References}

Abdulhameed, S., Pradeep, N.S., and Sugathan, S. (eds) (2017). Bioresources and bioprocess In biotechnology: Volume 1: Status and Strategies for exploration. Singapore, Springer.

Ankoma, M. G. (2014). Assessment of the current state of botanic gardens in Ghana and how they can be improved. Case-study-KNUST and Legon Botanic Gardens (Masters dissertation), Kwame Nkrumah University Of Science And Technology, Kumasi.

Ballantyne, R., Packer, J., Hughes, K. (2008). Environmental awareness, interests and motives of botanic gardens visitors: implications for interpretative practice. Tourism Management 29(3), 439-444.

Baloglu, S. \& Uysal, M. (1996). Market segments of push and pull motivations: a canonical 
correlation approach. International Journal of contemporary Hospitality Management, 3(8), 32-38. Botanic Gardens Conservation International. A vailable at URL: https://www.bgci.org/resources/1528/ (last accessed 05/11/2016)

Canny, I. U. (2013). An empirical investigation of service quality, tourist satisfaction and future behavioral intentions among domestic local tourist at Borobudur temple. International Journal of Trade, Economics and Finance 4 (2), 86 -91.

Carev, D. (2008). Guest satisfaction and guest loyalty study for hotel industry. MSc Thesis. Rochester, Rochester Institute of Technology.

Chan, J. K, L., \& Baum, T. (2007). Motivation factors of ecotourists in ecolodge accommodation: The push and pull factors. Asia Pacific Journal of Tourism Research, 12(4), $359-364$.

Chen, C. F., \& Chen, F. S. (2010). Experience quality, perceived value, satisfaction and behavioral intentions for heritage tourists. Tourism management, 31(1), 29-35.

Crilley, G., Hills, J., Cairncross, G., \& Moskwa, E. (2010). Identifying visitor service quality in Australian regional botanic gardens. Annals of Leisure Research, 13(3), 476-496.

Crompton, J. L. (1979). Motivations for pleasure vacation. Annals of Tourism Research, 6, 408424.

Cronin Jr, J. J., \& Taylor, S. A. (1992). Measuring service quality: A reexamination and extension. The journal of marketing, 55-68.

Dann, G. M. (1981). Tourist motivation an appraisal. Annals of Tourism Research, 8(2), 187219.

Diako, D. M. (2012). Discourses on autonomy and marital satisfaction among black women in dual-career marriages. Unpublished Doctoral dissertation, Pretoria, University of Pretoria.

Floy, J.A. (2015). Sustainable heritage tourism, climate change and the national trust. Birmingham, University of Birmingham.

Frempong, F., Dayour, F., \& Bondzi-Simpson, A. (2015). Visitor satisfaction with Ghana's tourist attractions. Oguaa Journal of Social Science, 7(3), 104-124.

Ghana Statistical Service (GSS, 2010). The national population and housing census. Accra, Ghana Statistical Service.

Gnoth, J. (1997). Tourism motivation and expectation formation. Annals of Tourism research, 24(2), 283-304.

Homburg, C., \& Giering, A. (2001). Personal characteristics as moderators of the relationship between customer satisfaction and loyalty - An empirical analysis. Psychology \& Marketing, 18(1), 43-66.

Iso-Ahola, S. E. (1982). Toward a social psychological theory of tourism motivation: A rejoinder. Annals of tourism research, 9(2), 256-262.

IUCN-BGCS \& WWF. (1989). The botanic gardens conservation strategy. IUCN Botanic Gardens Conservation Secretariat, Kew Richmond, WWF and IUCN.

Moore, D. L., \& Tarnai, J. (2002). Evaluating non-response error in mail surveys. In: Groves, R. M., Dillman, D. A., Eltinge, J. L., and Little, R. J. A. (eds.), Survey Nonresponse, John Wiley \& Sons, New York, pp. 197-211.

Munier, C., \& Camelis, C. (2013). Toward an identification of elements contributing to satisfaction with the tourism experience. Journal of Vacation Marketing, 19(1), 19-39.

Nworgu, B.G. (1991). Education research: Basic issues and methodology. Ibadan: Wisdom

Owusu, E. H. (2001). Community-based conservation in Ghana: The potential of the Afadjato and Agumatsa Range for ecotourism. Unpublished $\mathrm{PhD}$ thesis submitted to the University of Kent at Canterbury, Kent, UK.

Packer, J., \& Ballantyne, R. (2002). Motivational factors and the visitor experience: A comparison of three sites. Curator: The Museum Journal, 45(3), 183-198.

Pearce, P. L. (1991). Analysing tourist attractions. Journal of Tourism Studies 2(1), 46-55.

Pizam, A., Neumann, Y., \& Reicher, A. (1978). Dimensions of tourist satisfaction with a destination area. Annals of Tourism Research, 5 (3), 314-322.

Powledge, F. (2011). The evolving role of botanical gardens. BioScience; 61(10), 743-49. 
Ritchie, B. W., Tkaczynski, A., \& Faulks, P. (2010). Understanding the motivation and travel behavior of cycle tourists using involvement profiles. Journal of Travel \& Tourism Marketing, 27(4), 409-425.

Seibel, M. (2013). Forest canopy tourism: Analyzing a flagship attraction in the ecotourism arena from a political ecology perspective, Treetops at Risk. Springer, 361-365.

Singer, E., van Hoewyk, J., \& Maher, M. P. (2000). Experiments with incentives in telephone surveys. Public Opinion Quarterly 64, 171-188.

Smith, P. P. (2015). Tree conservation and the role of botanical gardens. BG Journal, 12(2), 1.

Smith, P. P. (2019). The challenge for botanic garden science. Plants, Planet \& People. 1, 38 43. https:// doi.org/10.1002/ppp3.10

Swarbrooke, J. (1999). The development and management of visitor attractions. Oxford: Linacre House.

Tlili, H. T. \& Amara, D. (2016). Towards emotional experience and place attachment as tourist satisfaction attributes. Journal of Business \& Economic Policy, 3(3), 108-119.

Uysal, M., \& Hagan, L. A. R. (1993). Motivation of pleasure travel and tourism. In Khan, M., Olsen, M. \& Var, T. (Eds.), Encyclopedia of Hospitality and Tourism, pp. 798-810.

Ward, C.D., Parker, C.M., \& Shackleton, C.M. (2010). The use and appreciation of botanical gardens as urban green spaces in South Africa. Urban For. Urban Green, 9, 49-55.

Wassenberg, C. L. (2012). Botanic garden user outcomes: A means-end investigation. MSc Dissertation. California Polytechnic State University, San Luis Obispo. Downloaded on 03/11/2019 at https://doi.org/10.15368/theses.2012.63

Wassenberg, C. L., Goldenberg, M.A., \& Soule, K. E. (2015). Benefits of botanical garden visitation: A means-end study. Urban Forestry and Urban Greening, 14, 148-155.

Wong, K. M., \& Musa, G. (2014). Retirement motivation among 'Malaysia my second home'participants. Tourism Management, 40, 141-154.

Wyse-Jackson, P. S. (1999). Experimentation on a large scale-an analysis of the holdings and resources of botanic gardens. Botanic Gardens Conservation News, 3(3), 27-30.

Yao, Y. (2013). Assessing tourist experience satisfaction with a heritage destination. Open Access Theses. 107. https://docs.lib.purdue.edu/open_access_theses/107.

Zhang, S, \& Chan, C. (2016). Nature-based tourism development in Hong Kong: Importanceperformance perceptions of local residents and tourists. Tourism Management Perspectives, $20,38-46$. 